\title{
College English Curriculum Reform and Practice Based on Culture Cognitive Analysis From the New Media Prospective*
}

\author{
GUO Hui \\ Qingdao University of Science and Technology, Qingdao, China
}

\begin{abstract}
With the increase of international cultural exchange, training and strengthening college students' cultural cognitive ability is a burgeoning research subject in today's foreign language teaching profession of colleges and universities. Cross-cultural communication skills and cultural cognition abilities have become an important measure of the ability of the modern language talents. This paper tries to implement a comprehensive reform of college English curriculum system through an empirical research in order to improve students' cultural cognitive abilities and cross-cultural communicative competence and change the non-ideal situation in college English teaching. Its valuable experience can greatly promote language teaching and help other universities reform their college English curriculum.
\end{abstract}

Keywords: new media, cultural cognition, college English curriculum reform

\section{Introduction}

With the increase of international cultural exchange, training and strengthening college students' cultural cognitive ability is a burgeoning research subject in today's foreign language teaching profession of colleges and universities. The training of cultural cognition ability in intercultural communication is gaining gradually attentions in foreign language teaching profession. For a long time, due to the traditional English teaching model influence, the students cannot successfully apply what they learned in the classroom to communicative context. Students have learned some cultural knowledge, but their culture cognitive abilities are generally poor. The traditional English curriculum needs to be reformed in order to change the current non-ideal situation of college English teaching quality. With the requirements of the times, the society needs communicative foreign language talents with solid cultural cognitive abilities and the college English curriculum reform is imperative. From the perspective of new media, this paper starts from the disadvantages of college English courses and implements the reforms and practices in the aspects of college English teaching curriculum, teaching mode and assessment methods in order to improve students' cultural cognitive ability and cultivate real communicative foreign language talents.

\footnotetext{
* This paper is the research result of teaching research and reform project of Academic Affairs Office in Qingdao University of Science and Technology (2014). GUO Hui, lecturer, master, School of Foreign Language, Qingdao University of Science and Technology.
} 


\section{An Overview of College English Curriculum Reform}

Since 2002, the reform of college English teaching has become a major project and the voice of college English curriculum reform is increasingly strengthened.

\section{Overview of College English Curriculum Reform Abroad}

After the World War II, the United States attaches great importance to foreign language education. Some European and Asian countries, such as France, Spain, etc., are also actively exploring foreign language education reform road. Foreign language education reforms abroad put emphasis on the evaluation of practical application of language ability and the foreign language application into the social life is the successful experience of foreign language education reforms. The principles to cultivate the language talents with an international perspective and cross-cultural awareness are reflected in terms of guiding, teaching content, teaching mode, and teaching methods.

\section{Overview of College English Curriculum Reform Domestic}

From the content point of view, most of the authors have studied the college English teaching reform (CETR) itself and foreign advanced concepts in the field of English teaching are embodied less in domestic college English teaching field. The problems are as follows: (1) Study content is relatively simple. Domestic scholars, for examples, JIA Guo-dong, QI Feng, WANG Zhen-ping, and so on, have published many articles with greater impact about CETR itself, teaching model, and teacher research. (2) More studies in classroom itself. There is new trend in teaching-focused research. (3) More emphasizes on multimedia and network teaching research. In recent years, "College English Curriculum Requirements” suggests that English teachers should make full use of multimedia and network technology in college English teaching and take the advantages of the new teaching model. (4) The proportion of papers based on empirical research is very small.

\section{Cultural Cognition Theory}

The concept of cultural cognition firstly appeared in the 1920s. American linguist Sapir (1921) pointed out in his book Language: Language has its environment and it cannot exist if separated from culture. It could not be divorced from traditions and beliefs inherited from society. Sapir also said that there is something behind the language and language cannot exist without culture. Successful language learners not only should have good language skills, but also better understand the differences between Western and native culture. They should flexibly apply cultural knowledge to real cross-cultural communication. Being familiar with culture helps students use language correctly, because culture is often a precursor of language.

Some internal scholars pointed out that cultural interference is one of the "problems" in foreign language teaching. They think cultural interference is even more frightening than "not understanding”. With the more communications between universities and society, college students should not only grasp the basic language skills, also should better understand the differences between their own culture and Western culture.

\section{The Process and Results of the Empirical Study}

From the new media perspective, this paper takes an empirical research on college students' cultural cognition abilities. The research results are the basis for the college English curriculum reform and reset. 


\section{Participant}

Research group designed the test content based on research objectives and extracted 400 non-English major students in Qingdao University of Science and Technology as the research samples. These samples are sophomore students coming from different majors, whose ages are between 19-21 years old and have been studying English for seven years.

\section{Methods: The Multimedia Teaching Model}

Using a combination of qualitative and quantitative methods, the research group divided those samples into experimental group and control group respectively with 200 students and started the experiment from June to November in 2014. First, research group designed the multimedia teaching model based on the Internet and the campus network and tried to adopt "traditional model + a personalized learning model" instead of the traditional mode teaching. The experimental group students adopted "traditional model + a personalized learning model". This new curriculum system is "classroom + teaching software + computer with network/learning system + tutorial”. Students learned basic knowledge of the language through the teaching in class and educational software, networks, and other self-learning mode out of class. Students also used the Internet and other new multimedia ways to learn cultural knowledge independently with regular supervision and guidance by the teacher.

However, the control group students adopted the traditional learning mode. After one semester, the research group conducted another cultural knowledge tests on these two groups of students and analyzed the achievements and results of the test by using the SPSS. The test scores of two groups of students were compared and the gaps of cultural cognition abilities between two groups of students were also analyzed.

\section{Results and Analysis}

Test results analyzed by SPSS are as follows:

Table 1

Pre-test and Post-test Results Analysis of Experimental Group

\begin{tabular}{llllll}
\hline & Chinese culture & Western culture & $\begin{array}{l}\text { Cross-cultural } \\
\text { communication }\end{array}$ & $\begin{array}{l}\text { Cultural cognition } \\
\text { contrast }\end{array}$ & Total average \\
\hline Pre-test & 4.20 & 3.63 & 5.26 & 4.73 & 14.82 \\
Post-test & 4.54 & 4.12 & 5.90 & 4.93 & 16.58 \\
Difference & 0.34 & 0.49 & 0.64 & 0.20 & 1.76 \\
$T$ & 1.766 & 2.232 & 3.156 & 3.033 & 4.162 \\
$P$ & 0.040 & 0.015 & 0.001 & 0.002 & 0.0001 \\
\hline
\end{tabular}

Table 2

Pre-test and Post-test Results Analysis of Control Group

\begin{tabular}{llllcc}
\hline & Chinese culture & Western culture & $\begin{array}{l}\text { Cross-cultural } \\
\text { communication }\end{array}$ & $\begin{array}{l}\text { Cultural cognition } \\
\text { contrast }\end{array}$ & Total average \\
\hline Pre-test & 3.66 & 4.30 & 5.20 & 3.95 & 14.04 \\
Post-test & 4.14 & 4.43 & 4.90 & 3.93 & 14.42 \\
Difference & 0.48 & 0.13 & -0.30 & -0.02 & 0.38 \\
$T$ & 1.542 & 1.210 & -0.848 & -0.045 & 0.604 \\
$P$ & 0.064 & 0.117 & 0.198 & 0.480 & 0.271 \\
\hline
\end{tabular}


The full score of the test paper is 35 and the score assignments are as follows: Western culture (10 points), traditional Chinese culture (10 points), cross-cultural communication (8 points), and cultural cognition contrast (7 points). Table 1 shows that the average score of the experimental group before the empirical study is 14.82 and the average score increases to 16.58 after the empirical test. The difference is 1.76 and $P=0.0001<0.05$ explains that the overall cultural cognitive abilities of the experimental group have been improved significantly after six-month training with the multimedia teaching model. From the analysis of the data in Table 1, it can be seen that all scores of four types of questions have been increased, and the differences are respectively $0.34,0.49,0.64$, and 0.20 . The data indicates that there is an overall increase in the experimental group's test performance and the difference is big between the pre-test and post-test scores.

Table 2 shows that the average score of the control group before the empirical study is 14.04 and the average score increases to 14.42 after the empirical test. The difference is only 0.38 and $P=0.271>0.05$ explains that the overall cultural cognitive abilities of the control group have not changed much after a six-month experiment with the traditional teaching model. The scores of cross-cultural communication and cultural cognition contrast questions are even lower than the scores before the empirical study. The differences are respectively $0.48,0.13$, -0.30 , and -0.02 . With the research results of two classes, it can be found that multimedia teaching mode greatly promoted students' cultural cognitive abilities and intercultural communicative competence.

\section{Conclusion and Suggestions}

\section{Conclusion}

From the above results of the empirical study, it is concluded that the students have a solid grasp of Western culture knowledge in class or out of class with the new media networks teaching mode, self-learning mode, cultural cognition teaching mode, and cultural inputs mode. This method not only strengthens the student's own traditional culture cognition abilities and Western culture cognition abilities, but also improves their cross-cultural communication skills. Being consistent with the quality-oriented education requirements, multimedia teaching mode and "traditional model + a personalized learning model" not only can improve students' performance in English, but also can cultivate the real foreign talents under a global cultural context.

\section{Suggestions}

Based on the results analysis, the specific measures for college English curriculum reform are drawn as follows:

(1) Set a reasonable course system: Cross-cultural communication and Western culture appreciation courses should be opened and English extracurricular activities should also be introduced.

(2) Improve the traditional teaching model: (a) Adopt multimedia network teaching mode. With networking, multimedia, projectors, video recorders, and other instructional media, students can be trained to quickly start cultural identity known systems in different language context and accurately select the appropriate communicative language; (b) adopt cultural cognition teaching mode and culture inputs teaching mode. Cultural cognition teaching activities can cultivate and improve students' cognitive abilities and reduce cultural misunderstanding or cultural conflicts; and (c) adopt individualized learning mode and independent study teaching mode. Language learning centers and independent network learning laboratories should be established. 
The reformed college English curriculum system improves students' cultural cognition abilities and cross-cultural communication abilities. The reformed college English curriculum system not only adapts to the requirements of cultural qualities education and real foreign languages talents cultivation, but also provide students with the opportunity to think independently and develop their independent learning abilities.

\section{References}

Berns, M. (1990). Context of competence: Social and cultural considerations in communicative language teaching. New York: Plenum Press.

Kinght, P., \& Yorke, M. (2004). Learning, curriculum and employability in higher education. New York, NY: Routledge Falmer. Kransch, C. (1993). Context and culture in language teaching. Oxford: Oxford University Press.

Sapir. E. (1921). Language: An introduction to study of speech (p. 221). New York: Harhcount, Brance \& Company.

Seeley, H. N. (1988). Teaching culture. Lincolnwood II: National Textbook Company.

Sperber, D., \& Wilson, D. (1995). Relevance: Communication and cognition. Oxford: Blackwell.

Tornalin, B., \& Stempleski, S. (1993). Culture awareness (p. 8). Oxford: Oxford University Press.

Valdes, J. M. (1996). Cultural bound: Bridging the cultural gap in language teaching. Cambridge: Cambridge University Press. 